\title{
PELATIHAN TENTANG KETERAMPILAN MEMBACA BAGI PARA GURU SEKOLAH DI KECAMATAN REGOL KOTA BANDUNG
}

\author{
Ahmad Agus Sulthonie ${ }^{1)}$, M. Taufiq Rahman ${ }^{2)}$ \\ ${ }^{1)}$ Fakultas Dakwah dan Komunikasi UIN Sunan Gunung Djati Bandung \\ ${ }^{2)}$ Fakultas Ilmu Sosial dan Ilmu Politik UIN Sunan Gunung Djati Bandung
}

\begin{abstract}
Abstrak
Tulisan ini merupakan hasil dari kegiatan pengabdian kepada masyarakat yang dilakukan dengan kajian penelitian. Kajian ini membahas tentang keefektifan pelatihan membaca bagi guru-guru Sekolah Menengah Pertama di Kecamatan Regol Kota Bandung. Tujuan kajian ini yakni untuk memahami bagaimana pelatihan tersebut dapat membawa kemajuan bagi guru-guru dalam membaca, sehingga dapat ditularkan kepada anak-anak didik mereka. Metode yang digunakan yaitu metode deskriptif dan teknik pengumpulan data yakni wawancara, observasi, dan studi pustaka. Hasil kajian menunjukkan bahwa pelatihan membaca dapat meningkatkan kemampuan dalam memilih, mencerna, menyampaikan, dan menggunakan bacaan. Kemampuan-kemampuan ini dapat ditingkatkan dengan cara sering berkesadaran pada materi-materi tentang membaca yang dilatihkan dalam pelatihan membaca di atas. Pada gilirannya kemampuan tersebut dapat ditransferkan kepada anak-anak didik para guru tersebut, seperti dalam laporan pendampingan dari kegiatan pengabdian kepada masyarakat.
\end{abstract}

Kata Kunci:, kecamatan regol, bandung, membaca cepat, pelatihan membaca.

\begin{abstract}
This paper is the result of community service activities conducted with research studies. This review discusses the effectiveness of reading training for Junior High School teachers in the Regol, Bandung. The purpose of this study is to understand how the training can bring progress to teachers in reading, so it can be transmitted to their students. The method used is descriptive method and data collection technique that is interview, observation, and literature study. The results of the study indicate that reading training can improve the ability to select, digest, convey, and use reading. These capabilities can be enhanced by often being aware of the reading material trained in the reading training above. In turn these capabilities can be transferred to the teachers' children, as in the accompaniment report of community.
\end{abstract}

Keywords: Bandung, fast reading reading training, regol district.

\section{PENDAHULUAN}

Keadaan kemampuan membaca para generasi muda saat ini sungguh tidak menggembirakan. Anak-anak sekolah sekarang ini sudah kurang lagi berkebiasaan membaca. Sebagaimana diungkapkan dalam ekspresi yang khas oleh sastrawan Taufik Ismail (2003: 5), melalui observasinya kepada beberapa siswa sekolah di kawasan ASEAN bahwa anak-anak Indonesia sekarang telah "rabun membaca" dan "lumpuh menulis".

Bukti yang menguatkan akibat dampak dari keadaan di atas ditunjukkan oleh hasil studi berbagai organisasi internasional, misalnya, International Educational Achievement (IEA) yang melaporkan bahwa kemampuan membaca siswa sekolah dasar Indonesia berada pada peringkat ke-38 dari 39 negara peserta studi. Menurut Third International Mathematics and Science Study (TIMMS), sebuah lembaga yang mengukur hasil pendidikan di dunia, dinyatakan bahwa kemampuan fisika para siswa SMP kita berada pada peringkat ke-32 dari 38 negara peserta (Taufik dkk., 2010). Hasil studi Human Development Report tahun 2000 versi UNDP disebutkan bahwa peringkat Human Development Index (HDI, Indeks Pembangunan Manusia) atau mutu sumber daya manusia (SDM) Indonesia berada pada urutan ke-105 dari 108 negara. Peringkat itu jauh di bawah Filipina (77), Thailand (76), Malaysia (61), Brunei Darussalam (32), Korea Selatan (30), dan Singapura (24). Kemudian, berdasarkan data dari Human Development Report (HDR), dengan 
data terakhir tahun 2014, Indonesia masih menempati urutan ke lima (5), di bawah Singapura, Brunei, Malaysia dan Thailand, dengan perolehan poin 0,684 . Sedangkan Singapura yang menempati posisi teratas yaitu 0,912 sekaligus menempati ranking 11 dunia. Tidak diragukan lagi di sini Singapura menjadi peringkat teratas dan menempati ranking tinggi di dunia, karena memang Singapura merupakan negara maju. Tapi tentu saja dengan berada di bawah Malaysia dan Thailand telah menjadikan posisi Indonesia masih belum bagus di ASEAN (UNDP, 2016).

Sebetulnya masih banyak bukti yang menunjukkan mutu SDM Indonesia berada di bawah negara-negara tetangga di kawasan ASEAN. Namun untuk latar belakang pemikiran untuk pengabdian ini cukuplah kiranya data-data di atas mendukung urgensi dari pengabdian kepada masyarakat ini.

Pertanyaannya adalah apakah sebab bahwa hasil pendidikan kita bisa terpuruk seperti itu? Tentunya kita harus secara cermat mencari akar dari segala permasalahan yang melanda dunia pendidikan kita sehingga sampai menghasilkan SDM yang sedemikian rendah kualitasnya. Tarigan dkk. (1989), dalam buku suntingannya Membaca dalam Kehidupan mengatakan bahwa sejarah peradaban manusia memang menggelinding terutama dikemudikan oleh kegiatan membaca. Akan tetapi, mengempis dan menggelembungnya peradaban suatu bangsa bukan hanya ditentukan oleh minat dan intensitas kegiatan membaca yang dilakukan oleh bangsa tersebut, melainkan juga sangat ditentukan oleh faktor lain yang langka tetapi lebih penting yaitu: tersedianya bahan bacaan, guru membaca, dan kebiasaan membaca. Sebagai perbandingan diberikan contoh pengembangan kemampuan membaca dan menulis yang diterapkan pada siswa SMP-SMA di negara-negara yang mutu SDM-nya di atas negara kita.

Siswa SMA di Malaysia pada tahun 2003 diwajibkan membaca novel sebanyak 12 buah, 18 cerita pendek, 8 drama, 18 puisi modern, 18 puisi tradisional, dan 12 prosa tradisional. Sebagai perbandingan, dengan rasa khawatir kita saksikan SMA Indonesia masih saja kini melompat-lompat di tempat, di titik nol buku sastra secara nasional (Ismail, 2003).

Mengenai aktivitas membaca, Arthur Applebee dkk. (1993) melaporkan hasil penelitiannya di 1210
SMP-SMA Amerika Serikat, kelas 7 sampai dengan 12 (1989) seperti pada tabel 1.

Tabel 1. Hsil Penelitian Applebee (1993)

\begin{tabular}{|l|l|l|}
\hline Kelas & $\begin{array}{l}\text { Per } \\
\text { Minggu }\end{array}$ & $\begin{array}{l}\text { Per } \\
\text { Tahun }\end{array}$ \\
\hline Kelas 7-8 (SMP kelas 1-2) & 30 hal & 1080 hal \\
\hline $\begin{array}{l}\text { Kelas 9-10 (SMP kelas 3, } \\
\text { SMA kelas 1) }\end{array}$ & 32 hal & 1152 hal \\
\hline Kelas 11-12 (SMA kelas 2-3) & 51 hal & 1836 hal \\
\hline
\end{tabular}

Dapat dinyatakan, siswa SMP di negara itu selama tiga tahun membaca 3312 halaman dan siswa SMA sepanjang 3 tahun membaca 4824 halaman. Ketika dia masuk perguruan tinggi, selama 6 tahun di SMP-SMA dia telah terlatih membaca 8136 halaman. Ini baru buku bacaan sastra wajib, belum dihitung buku bacaan wajib di mata pelajaran lainnya, seperti Sejarah, Ekonomi, Civics, dan lainlain yang tidak diteliti. Dengan demikian, ketika memasuki universitas, siswa-siswa ini sudah 6 tahun terlatih membaca ribuan halaman sehingga tidak canggung mengikuti kencangnya ritme membaca buku teks di perguruan tinggi (Applebee dkk., 1993).

Di dalam laporannya yang berjudul The American High School Today, James B. Conant (1995) menyebutkan bahwa siswa SMA di Amerika Serikat diharuskan menulis rata-rata satu tema seminggu, artinya satu judul satu minggu. Agar terukur hasil yang dicapai, lebih baik kita merujuk jumlah karangan yang ditulis siswa, bukan jumlah pertemuan. Pada setiap pertemuan di kelas dipergunakan untuk mendiskusikan karangan. Dengan demikian, dalam satu semester siswa membuat 18 karangan, setahun 36 karangan, 3 tahun sebanyak 108 karangan.

Beban tugas menulis yang banyak itu dapat dipikul oleh siswa karena tata bahasa tidak lagi diajarkan di SMA. Bukan berarti tata bahasa dilenyapkan, tetapi di SMA penggunaan tata bahasa dicek melalui tulisan siswa. Begitulah yang berlangsung di SMA Singapura, Malaysia, Kanada, Jepang, Swiss, Rusia, Jerman, Perancis, Belanda, dan Amerika (Ismail, 2003). 
Dalam hal pelajaran menulis, siswa SMP Kolej Melayu Kuala Kangsar (1980), dalam setahun siswa menulis 81 halaman sedangkan untuk tingkat SMA Kolej Melayu Kuala Kangsar (1980) setiap tahun mereka menulis 504 halaman. Dari 7 tahun pengajaran menulis di SMP-SMA Kolej Kuala Kangsar, di kelas 2 dan 3 SMA titik beratnya diletakkan pada latihan penulisan esai atau artikel (2000 kata seminggu) dengan keharusan rujukan kepustakaan (Ismail, 2003).

Sebagai bahan perbandingan, titik berat pengajaran penulisan di 1210 SMA (4 tahun) Amerika Serikat, ternyata titik berat yang sangat mencolok diletakkan pada latihan penulisan esai, di antara $78,6 \%$ sampai dengan $89,8 \%$ untuk keempat kategori SMA (unggulan, negeri, swasta, dan Katolik).

Pada catatan II, Ismail (2003: 15) mengatakan bahwa tentu saja kita ingin anak- anak didik kita, setamat SMA sudah terlatih membaca beberapa ribu halaman buku. Untuk masa jangka pendek di depan kita, dapatkah kita ikhtiarkan beberapa ratus halaman saja? Secara bertahap kita harus mencapai lagi kualifikasi buku sastra wajib seperti di AMS Hindia Belanda. Akan tetapi, agar anak didik kita membaca, tentulah pertama-tama gurunya harus jadi teladan membaca dulu. Untuk itu, guru-guru harus kita siapkan.

Berdasarkan ilustrasi di atas, dapat dipahami bahwa keterampilan membaca merupakan dua keterampilan berbahasa yang sangat penting dan memegang kunci keberhasilan dan kemajuan bangsa. Oleh karena itu, keterampilan membaca tidak hanya menjadi tanggung jawab guru bahasa saja tetapi juga guru-guru di luar bidang studi bahasa, karena "every teacher is a reading teacher" (setiap guru adalah guru membaca). Di lain pihak, pengembangan bidang studi lain sangat memerlukan kemampuan membaca (Applebee dkk., 1993).

Matematika sebagai salah satu bidang studi yang di dalamnya dikembangkan aspek-aspek seperti: pemecahan masalah, komunikasi, penalaran, pemahaman konsep, dan prosedur sangat memerlukan dukungan dari kemampuan membaca dan menulis. Sebagai contoh, pengungkapan pentingnya komunikasi dalam pembelajaran matematika, dapat ditemukan dalam berbagai buku pelajaran matematika yang digunakan siswa setingkat SMP di Amerika Serikat. Salah satu contohnya adalah dalam buku Connected Mathematics Project (2002), sebagai buku kurikulum pendidikan matematika dari Kementerian Pendidikan Amerika Serikat. Demikian juga dalam buku Mathematics: Applications and Connections yang diterbitkan oleh Glencoe/McGraw-Hill disebutkan salah satu tujuan yang ingin dicapai melalui buku tersebut adalah memberikan kesempatan seluas-luasnya kepada para siswa untuk mengembangkan dan mengintegrasikan keterampilan berkomunikasi melalui modelling, speaking, writing, talking, drawing serta mempresentasikan (presenting) apa yang telah dipelajari (Collins, dkk., 1998).

Menurut Baroody (1993) pada pembelajaran matematika dengan pendekatan tradisional, komunikasi (lisan) siswa masih sangat terbatas hanya pada jawaban verbal pendek atas berbagai pertanyaan yang diajukan oleh guru. Bahkan menurut Cai dkk. (1996) "it is so rate for students to provide explanation in mathematics class, so storage to talk about mathematics and so surprising to justify answers' [adalah rata-rata bagi siswa untuk memberikan penjelasan di kelas matematika, juga begitu banyak yang dapat dibicarakan tentang matematika dan begitu banyak kejutan dalam membenarkan jawaban].

Komunikasi matematika perlu menjadi fokus perhatian dalam pembelajaran matematika sebab melalui komunikasi siswa dapat mengorganisasi berpikir matematisnya dan siswa dapat mengeksplorasi ide-ide matematika (NTCM, 2000). Selain itu, menurut Atkins (1999) komunikasi matematika secara verbal merupakan "a tool for measuring growth in understanding, allow participants to learn about the mathematical constructions from others, and give participants' opportunities to reflect on their own mathematical understanding" [alat untuk mengukur pertumbuhan dalam pemahaman, memungkinkan peserta untuk belajar tentang konstruksi matematis dari orang lain, dan memberi kesempatan kepada para peserta untuk merefleksikan pemahaman matematika mereka sendiri].

Berbagai pendapat di atas dapat dimaknai bahwa kemampuan siswa dalam berkomunikasi dalam bidang matematika dan bidang studi lainnya sangat penting untuk diungkapkan. Oleh karena itu, pelatihan membaca bagi guru-guru sekolah 
menengah pertama menjadi penting dan strategis, yang pada gilirannya dapat diimbaskan kepada peserta didik di sekolah masing-masing. Pelatihan membaca akan sangat bermakna manakala guru dapat menjadi model membaca. Oleh karena itu, melalui pelatihan ini diharapkan para guru memperoleh pengalaman, pengetahuan, dan wawasan yang layak baik untuk kepentingan yang bersangkutan dalam mengembangkan diri dan bersikap profesional maupun untuk kepentingan pendidikan di sekolah.

Para guru sekolah menengah pertama sebagai ujung tombak keberhasilan pendidikan masih belum banyak dilibatkan dalam mengatasi berbagai masalah pendidikan khususnya dalam kegiatan membaca. Disadari bahwa kegiatan membaca merupakan kompetensi dasar yang harus dimiliki oleh setiap siswa. Dalam kenyataannya, sebagaimana diungkapkan dalam analisis situasi di atas bahwa kemampuan membaca para siswa sekolah menengah pertama belum menggembirakan. Oleh karena itu, upaya nyata perlu dilakukan segera agar permasalahan kemampuan membaca peserta didik termasuk guru-gurunya dapat diatasi. Berdasarkan hal itulah permasalahan pelatihan ini dapat dirumuskan — bagaimanakah model pelatihan membaca yang efektif bagi guru-guru sekolah menengah pertama?

Secara spesifik perumusan masalah pelatihan membaca bagi guru-guru sekolah menengah pertama dapat dirumuskan sebagai berikut:

1. Bagaimanakah model pelatihan membaca yang efektif bagi guru-guru sekolah menengah pertama?

2. Bagaimanakah teknik penyajian pelatihan membaca yang dipandang efektif bagi guru-guru sekolah menengah pertama?

3. Bagaimanakah tujuan yang diharapkan dari hasil pelatihan membaca bagi guru-guru sekolah menengah pertama?

4. Bagaimanakah materi yang sesuai dengan kebutuhan peserta pelatihan membaca bagi guruguru sekolah menengah pertama?

5. Bagaimanakah tindak lanjut pelatihan membaca yang sesuai dengan kebutuhan guru-guru sekolah menengah pertama?

Setelah mengikuti pelatihan membaca ini diharapkan para guru sekolah menengah pertama di Kecamatan Regol Kota Bandung dapat menerapkan kemampuan membaca berbahasa Indonesia sehingga mampu meningkatkan keterampilan berbahasa Indonesia yang baik dan benar. Di samping itu, manfaat yang dapat diperoleh dari kegiatan ini adalah para guru dapat menciptakan iklim kelas yang kondusif untuk terus belajar melalui aktivitas membaca sehingga dapat membuat suasana kelas menjadi lebih menyenangkan.

Di samping manfaat secara akademik, para guru juga dapat mengembangkan kemampuan diri melalui kegiatan membaca. Membaca bisa dipandang sebagai kebutuhan guru. Setiap aktivitas belajar tidak lepas dari kegiatan membaca. Oleh karena itu, guruguru dipandang kreatif dan profesional ketika dia banyak membaca. Demikian sehigga, pada saatnya guru-guru pun dapat menulis. Hasil tulisan guru berupa laporan sangat penting untuk pengembangan karier dan profesinya

\section{TINJAUAN PUSTAKA}

Pelatihan membaca bagi guru-guru sekolah menengah pertama di Kecamatan Regol Kota Bandung ini bertujuan agar para guru memperoleh bekal pengetahuan, pengalaman, dan keterampilan yang memadai dalam membaca. Membaca sangat penting bagi guru, apakah untuk kepentingan pendidikan dan pengajaran, kepentingan pengembangan diri guru yang profesional, maupun untuk kepentingan karier.

Sesuai dengan perumusan masalah, secara spesifik tujuan pelatihan membaca ini adalah sebagai berikut:

1. Menerapkan model pelatihan membaca yang efektif bagi guru-guru sekolah menengah pertama.

2. Menerapkan teknik penyajian pelatihan membaca yang dipandang efektif bagi guru-guru sekolah menengah pertama.

3. Terwujudnya jenis-jenis laporan/tulisan peserta dari hasil pelatihan membaca bagi guru-guru sekolah menengah pertama.

4. Terpilihnya materi pelatihan yang sesuai dengan kebutuhan peserta pelatihan membaca bagi guruguru sekolah menengah pertama.

5. Adanya kesinambungan/ tindak lanjut pelatihan membaca yang sesuai dengan kebutuhan guruguru sekolah menengah pertama.

Pelatihan Membaca ini seharusnya adalah training 4 sesi yang akan menjelaskan dasar 
keterampilan membaca cepat. Peserta akan memiliki pemahaman tentang pentingnya membaca cepat, menghilangkan kebiasaan buruk dalam membaca, serta menerapkan teknik dasar dan strategi membaca cepat untuk menjadi individu yang lebih produktif.

Sesi pertama ini akan mengajak peserta mengenal secara umum apa sebenarnya membaca cepat dan cara menghitung kecepatan baca saat ini.

1. Apa manfaat membaca cepat buat peserta sebagai pribadi maupun profesional di kantor.

2. Bagaimana menghitung dan memperkirakan kecepatan baca saat ini.

3. Menentukan target dan prioritas untuk meningkatkan kecepatan baca.

Pada sesi kedua, peserta diajak untuk mengenali kebiasaan buruk dalam membaca dan mempraktekkan strategi untuk menghilangkannya serta mulai mempelajari teknik dan strategi dasar membaca cepat. Sesi ini akan menjelaskan:

1. Bagaimana mengenali kebiasaan yang baik dan buruk dalam membaca.

2. Bagaimana menghilangkan kebiasaan buruk dalam membaca.

3. Strategi dasar membaca cepat dengan teknik membaca beberapa kata sekaligus dan mempercepat perpindahan antar kata dan antar fiksasi.

4. Cara melatih variasi lebar dan irama fiksasi mata. Sesi ketiga berkonsentrasi membantu peserta agar sanggup membaca secara aktif dan kritis. Di sini tujuannya adalah:

1. Mengenal cara membaca secara aktif dan kritis dengan Metode Preview.

2. Mengenal cara membaca secara aktif dan kritis dengan Metode SQ3R.

3. Teknik membaca skimming, scanning dan skipping sebagai pendukung keterampilan membaca cepat.

Pada sesi keempat peserta akan belajar bagaimana meningkatkan kecepatan dan pemahaman dalam membaca. Dalam sesi penutup ini peserta akan belajar:

1. Mengenali bagaimana proses mengingat dan memahami bekerja.

2. Menguasai faktor penentu kecepatan dan pemahaman seseorang.

3. Mengatasi hambatan fisik dan mental dalam membaca.
Dalam Kamus Kamus Besar Bahasa Indonesia (KBBI) pembinaan minat membaca adalah perhatian atau kesukaan. Hakikat Pembinaan minat membaca adalah "Perhatian atau kesukaan (Kecenderungan hati) kepada sesuatu". Mengacu kepada makna itu maka dalam hal ini pemberdayaan pembinaan minat membaca berarti adanya perhatian atau kesukaan (kecenderungan) untuk membaca.Kecenderungan atau kesukaan membaca itu perlu dibina sejak kecil. Pembinaan dan pengembangan merupakan kegiatan yang berhubungan dengan pemeliharaan, penyempurnaan, dan peningkatan. Misalnya pembinaan dan pengembangan prestasi murid. Sedangkan pembinaan dan pengembangan minat baca berarti usaha memelihara, mempertahankan, dan meningkatkan minat baca. Apabila minat baca para peserta didik/siswa sulit untuk ditingkatkan maka minimal harus diperhatikan. Minat sering diartikan sebagai "interest". Minat bisa dikelompokkan sebagai sifat atau sikap (traits of attitude) yang memiliki kecenderungan atau tendensi tertentu. Minat tidak bisa dikelompokkan sebagai pembawaan tetapi sifatnya bisa diusahakan, dipelajari dan dikembangkan. Membaca merupakan suatu proses menangkap atau memperoleh konsepkonsep yang dimaksud oleh pengarangnya, menginterpretasi, mengevaluasi konsep-konsep pengarang dan merefleksikan atau bertindak seperti yang dimaksud dalam konsep itu. Kemampuan membaca tidak hanya mengoperasikan berbagai keterampilan untuk memahami kata-kata dan kalimat tetapi juga kemampuan untuk menginterpretasi, mengevaluasi sehingga diperoleh pemahaman yang komprehensif. Dalam rangka mengemban misi perpustakaan di lembaga pendidikan, pengelola perpustakaan harus berusaha semaksimal mungkin untuk membina minat baca para siswa. Pengelola perpustakaan harus benarbenar memahami prinsip-prinsip dan karakteristik membaca yang baik, cara-cara memotivasi para pemustaka supaya senang membaca. Dari sini dapat dilihat betapa pentingnya Pustakawan mesti memiilki pengetahuan dan keterampilan yang berkaitan dengan penyediaan informasi serta keahlian dalam menggunakan berbagai sumber, baik tercetak maupun elektronik (Suherman, $2009: 30$ ). Sesungguhnya pustakawan adalah seorang yang mesti memiliki kompetensi yang diperoleh melalui 
pendidikan atau pelatihan kepustakawanan serta mempunyai tugas dan wewenang secara profesional.

Beberapa prinsip membaca yang perlu diperhatikan oleh pengelola / pustakawan dalam membina dan mengembangkan minat baca adalah sebagai berikut:

1. Membaca merupakan proses berpikir yang kompleks. Hal ini terdiri dari sejumlah kegiatan seperti memahami kata-kata atau kalimat yang ditulis oleh pengarang, menginterpretasikan konsep-konsep pengarang serta menyimpulkannya;

2. Kemampuan membaca tiap orang berbeda-beda. Setiap orang memiliki kemampuan membaca sendiri-sendiri tergantung pada beberapa faktor. Misalnya tingkatan kelas, kecerdasan, keadaan emosi, hubungan sosial seseorang, latar belakang pengalaman yang dimiliki, sikap, aspirasi, kebutuhan-kebutuhan hidup seseorang, dan sebagainya;

3. Pembinaan kemampuan membaca atas dasar evaluasi pembinaan tersebut harus dimulai atas dasar hasil evaluasi terhadap kemampuan membaca orang yang bersangkutan;

4. Membaca harus menjadi pengalaman yang memuaskan. Seseorang akan senang jika telah berhasil mempelajari sesuatu dengan baik dan merasa puas atas hasil bacaannya;

5. Kemahiran membaca perlu keahlian yang kontinyu, agar memiliki kemahiran membaca, keterampilan-keterampilan yang dibutuhkan dalam membaca perlu diperhatikan sedini mungkin sejak seseorang pertama kali masuk lembaga pendidkan;

6. Evaluasi yang kontinyu dan komprehensif merupakan batu loncatan dalam pembinaan minat baca. Dalam kegiatan pembinaan dan pengembangan minat baca para peserta didik harus selalu disertai kegiatan evaluasi karena untuk mengetahui keberhasilan pembinaan dan pengembangan minat baca para peserta diidik;

7. Membaca yang baik merupakan syarat mutlak keberhasilan belajar. Agar memperoleh keberhasilan belajar, seseorang harus membaca secara efisien.

Sasaran dari pelaksanaan perpustakaan adalah terbentuknya masyarakat yang mempunyai budaya membaca dan belajar sepanjang hayat (Dian Sinaga, 1997:1). Empat hal yang harus diperhatikan dalam membina minat baca melalui pelayanan perpustakaan, yaitu:

1. Usaha untuk menarik pembaca agar datang ke perpustakaan dan memiliki kegemaran membaca yang dilakukan pengelola perpustakaan/ pustakawan yaitu:

a. Kunjungan perpustakaan: Dengan kunjungan ini diharapkan pengunjung perpustakaan memperoleh informasi dengan melihat sendiri dan mengamati secara teratur sehingga mengetahui koleksi perpustakaan dan menimbulkan rasa ingin membaca atau meminjam buku di perpustakaan.

b. Publikasi: Perlu adanya wadah untuk memberitahukan pada pemakai perpustakaan tentang adanya buku-buku baru dan buku referensi baru. Hal ini bisa dilakukan melalui tulisan, petunjuk brosur dan tulisan lain.

c. Pameran: Pameran dilakukan untuk memperkenalkan koleksi yang tersedia di perpustakaan.

d. Rangsangan kegiatan membaca: Untuk merangsang kegiatan membaca dapat diselenggarakan diskusi, kegiatan ilmiah, ceramah, pembacaan puisi atau prosa, dan sebagainya.

2. Bimbingan membaca.

3. Petugas perpustakaan/ pengelola/ Pustakawan hendaknya memilki sikap ramah, mempunyai disiplin kerja yang tinggi, terbuka, suka menolong dan menyenangkan pemustaka/pembaca.

4. Fasilitas perpustakaan harus memiliki fasilitas yang memadai, ini akan membawa pengaruh yang baik terhadap pemustaka. Fasilitas-fasilitas tersebut antara lain : koleksi buku yang memadai, perabot, penerangan yang cukup baik, sirkulasi udara yang cukup baik, adanya ruang diskusi/ceramah, ruang pandang dengar, toilet, dan sebagainya.

Secara umum menurut (Suherman, 2009: 48-49) Perpustakaan itu adalah sebuah pusat belajar, oleh karena itu, ia harus memungkinkan untuk dapat mengakomodasi berbagai macam aktivitas instruksional pada waktiu yang bersamaan. Tempattempat khusus yang mesti ada di perpustakaan. Dengan uraian Sbb:
a. Ruang Referensi (Reference Area)
b. Ruang bercerita (Booktalking/Storytelling area) 
c. Ruang Komputer (Computer/Technology area)

d. Ruang kelas (Intructional/Classroom Area)

e. Ruang Santai (Quiet study / recreational reading area)

f. Ruang Produksi (Multimedia Production)

g. Ruang Pengolahan Bahan Pustaka (Stroge/processing workroom)

\section{METODOLOGI}

Ada tiga faktor penting dalam penguasaan keterampilan untuk belajar: pertama adalah pola pikir dan sikap (mindset and attitude) kita terhadap belajar. Kita harus memiliki hasrat (desire) dan kecintaan (passion) yang dalam terhadap nilai-nilai untuk terus belajar dan mengembangkan diri. Belajar tidak hanya sekedar melalui pendidikan formal semata, tetapi dalam setiap aspek kehidupan kita harus senantiasa mengembangkan sikap belajar. Sikap mau membaca, mendengar, mengerti, dan belajar dari orang lain merupakan sikap yang perlu senantiasa dikembangkan jika kita ingin memperbaiki diri ataupun gagasan kita.

Faktor kedua dalam meningkatkan keterampilan untuk belajar adalah kemampuan kita untuk mendayagunakan kekuatan pikiran kita (terutama pikiran bawah sadar -subconscious mind) untuk mempercepat proses belajar (accelerated learning). Pikiran bawah sadar merupakan kekuatan yang luar biasa jika kita dapat mengoptimalkan potensinya.

Seringkali kita melupakan bahwa anugerah yang terindah dan terbesar yang diberikan Tuhan kepada kita adalah kemampuan pikiran kita. Hal inilah yang membedakan kita dengan ciptaan-Nya yang lain. Hal yang paling mudah kita lakukan untuk mengembangkan keterampilan untuk belajar adalah dengan banyak membaca. Meluangkan waktu sedikitnya satu jam sehari untuk membaca buku merupakan kebiasaan yang baik bagi kita untuk mulai mengembangkan diri kita.

Membaca, terutama membaca pemahaman bukanlah sebuah kegiatan yang pasif. Sebenarnya, pada peringkat yang lebih tinggi, membaca itu, bukan sekedar memahami lambang-lambang tertulis, melainkan pula memahami, menerima, menolak, membandingkan dan meyakini pendapat-pendapat yang ada dalam bacaan. Membaca pemahaman inilah yang dibina dan dikembangkan secara bertahap pada sekolah (Tampubolon, 1987).
Lebih dari itu, Tulalessy (1995) berpendapat bahwa membaca mahir (avented reading) harus mulai diajarkan pada siswa kelas 1 SMP sehingga siswa bisa menuju pada membaca di seberang baris (reading beyond the lines).

Banyak sekali metode untuk meningkatkan kecepatan membaca (speed reading) maupun pemahaman (comprehension) terhadap isi dari suatu buku. Keterampilan inilah yang amat kita perlukan untuk meningkatkan daya serap dan kecepatan kita dalam membaca sebuah buku. Selain membaca, meningkatkan kemampuan dapat diperoleh melalui seminar, pelatihan, maupun mendengarkan ceramahceramah motivasi.

Faktor ketiga dalam meningkatkan kemampuan belajar kita adalah disiplin diri dan kegigihan (self discipline and persistence). Tanpa kedua hal ini, belajar hanyalah kegiatan yang sifatnya tergantung suasana hati (mood) dan kita tidak dapat mencapai keunggulan (excellence) hanya dengan belajar setengah hati.

Sudah saatnya kita mengubah kebiasaan-kebiasaan kita. Ada pepatah yang mengatakan, "your habits will determine your future". Miliki kebiasaan belajar, dan mulai langkah pertama kita. Proses mengubah kebiasaan sangat ditentukan oleh kedisiplinan diri dan kegigihan kita sehingga setelah melakukannya dalam periode waktu tertentu. Hal tersebut tidak lagi menjadi beban tetapi telah menjadi kebutuhan. Jika pada awalnya sulit melakukan, setelah itu kita jadi terbiasa.

\section{HASIL DAN PEMBAHASAN \\ Gambaran Umum Masyarakat Regol}

Pelatihan membaca bagi guru-guru sekolah menengah pertama di Kecamatan Regol Kota Bandung ini bertujuan agar para guru memperoleh bekal pengetahuan, pengalaman, dan keterampilan yang memadai dalam membaca. Tulisan sebagai suatu karya memiliki makna yang sangat penting bagi guru, apakah untuk kepentingan pendidikan dan pengajaran, kepentingan pengembangan diri guru yang profesional, maupun untuk kepentingan karier (kenaikan pangkat dan jabatan). Di sinilah guru-guru mesti selalu melatih diri untuk membaca. 
Sebagai bagian dari Kota Bandung, Kecamatan Regol memiliki 7 kelurahan, yang terdiri dari kelurahan ciseureuh, pasirluyu, ancol, cigereleng, ciateul, pungkur dan Balonggede. Kecamatan Regol terdiri dari 60 rukun warga dan 373 rukun tetangga. Kelurahan Cigereleng memiliki jumlah RW dan RT terbanyak dengan $12 \mathrm{RW}$ yang terdiri dari $62 \mathrm{RT}$, sedangkan Kelurahan Pungkur memiliki jumlah RW dan RT paling sedikit yaitu 6 RW dan 46 RT.

Dalam menjalankan pemerintahan Kecamatan Regol, baik pegawai Kecamatan maupun pegawai kelurahan yang ada bekerja dengan dibantu oleh Rukun Warga (RW) dan Rukun Tetangga (RT) yang ada di kecamatan. Di Kecamatan Regol, terdapat 60 RW yang dibagi menjadi 373 RT. Ketua RW dan Ketua RT beserta masing-masing strukturalnya ikut serta berpartisipasi aktif dalam menjalankan program maupun kegiatan pembangunan di Kecamatan Regol.

Pendidikan merupakan sarana pembangunan manusia untuk kemajuan suatu wilayah. Pada Tahun 2015, sarana pendidikan formal atau yang disebut dengan sekolah di Kecamatan Regol ada sebanyak 88 buah. Angka terseut terdiri dari 27 SD/MI Negeri, 16 SD/MI Swasta,4 SMP/MTs Negeri, 10 SMP/MTS Swasta, 1 SMA Negeri dan 8 SMA Swasta. Tidak ditemukan Perguruan Tinggi Negeri maupun Perguruan Tinggi Swasta. Sedangkan, pendidikan prasekolah seperti Taman Kanak-kanak (TK) atau sederajat ada sebanyak 22 buah. Dari 1507 orang guru yang berada di Kecamatan Regol sebanyak 660 guru mengajar di institusi pendidikan SD dan 509 guru mengajar di institusi pendidikan SMP sedang sisanya sebanyak 243 guru mengajar di SMU/ Sederajat..

\section{Komunitas Sasaran Program}

Tabel 1 Peserta Kegiatan

\begin{tabular}{|l|l|l|}
\hline No. & Guru di Sekolah & Jumlah orang \\
\hline 1. & SMP Sebelas Maret & 16 orang \\
\hline 2. & SMP YAMI & 3 orang \\
\hline 3. & SMP Budi Istri & 2 orang \\
\hline 4. & SMP Nugraha & 2 orang \\
\hline 5. & SMP Pahlawan Toha & 2 orang \\
\hline 6. & SMP Dewi Sartika & 2 orang \\
\hline 7. & SMP Nusantara & 2 orang \\
\hline
\end{tabular}

\begin{tabular}{|l|l|l|}
\hline 8. & SMP Ganesha & 2 orang \\
\hline 9. & SMP BPI 1 & 1 orang \\
\hline 10. & SMP As-Salam & 2 orang \\
\hline 11. & SMP Pasundan 5 & 1 orang \\
\hline 12. & SMP YPKP & 2 orang \\
\hline 13. & SMP Pasundan 2 & 2 orang \\
\hline 14. & SMP Yudistira & 3 orang \\
\hline 15. & SMP Al-Gozali & 3 orang \\
\hline 16. & SMP Pasundan 1 & 1 orang \\
\hline 17. & SMP Pasundan 7 & 1 orang \\
\hline 18. & SMP Pasundan 9 & 1 orang \\
\hline 19. & SMP BPPI Bojong & 1 orang \\
\hline 20. & SMP Mutiara 3 & 1 orang \\
\hline 21. & SMP YPS & 1 orang \\
\hline 22. & SMP Cokroaminoto & 1 orang \\
\hline 23. & SMP Jenderal Sudirman & 1 orang \\
\hline 24. & SMP Wiyata Darma & 1 orang \\
\hline 25. & SMP Muhammadiyah 7 & 1 orang \\
\hline 26. & SMP Plus Sindang Resmi & 1 orang \\
\hline 27. & MTs At-Tazhimiyyah & 2 orang \\
\hline 28. & MTs Sirna Miskin & 1 orang \\
\hline 29. & MTs Nurrohmah & 1 orang \\
\hline Jumlah & & 60 orang \\
\hline & & \\
\hline
\end{tabular}

Fasilitas pendidikan di Kecamatan Regol sudah sangat memadai, dilihat dari ketersediaan dan jumlah fasilitas yang ada. Jika kita perhatikan rasio guru dan murid pun sudah relatif baik. Rasio guru dan murid tertinggi adalah pada jenjang pendidikan SD, yaitu terdapat satu orang guru untuk 21 murid SD. Adapun rasio guru dan murid untuk SMP adalah 13, sedangkan rasio guru dna muris SMU adalah 11. Artinya untuk sebelas murid SMU tersedia satu orang guru.

Namun demikian, karena terdapat kendalakendala teknis, ada beberapa guru yang bukan dari Kecamatan Regol yang mengikuti pelatihan membaca ini. Oleh karena itu, khalayak sasaran pelatihan membaca ini adalah guru-guru dan kepala sekolah yang tersebar di 29 SMP/MTs di Kecamatan Regol dan sekitarnya di Kota Bandung. Peserta adalah 60 orang guru dari 28 SMP/Tsanawiyah swasta di Kota Bandung ditambah satu sekolah lagi menyusul, jadi 29 sekolah, yaitu tambahan dari BPI 
1 sedianya tidak mengirim peserta, pada kenyataannya mengirim 1 orang utusan.

Para guru yang dilatih tersebut berlatarbelakang berbagai macam bidang yang diampu. Sehingga kegiatan ini diarahkan pada pelatihan membaca cepat yang bisa diterapkan bagi semua mata pelajaran

\section{Tahapan Kegiatan Pengabdian Masyarakat}

Bentuk kegiatan yang dipilih dalam pelatihan ini adalah para guru dihadapkan dengan masalahmasalah membaca. Penyaji bertindak sebagai fasilitator. Peserta dan penyaji secara bersama-sama mengamati kondisi nyata yang dialami setiap sekolah, siswa yang kurang aktivitas membaca, bahkan guru-guru itu sendiri yang jarang melakukan kegiatan membaca.

Dari refleksi seperti itulah diupayakan kerangka pemecahan masalah, di antaranya perlu adanya sarana perpustakaan yang memadai di sekolah. Disinyalir bahwa perpustakaan sekolah menengah pertama sebagian besar hanya terdiri atas buku-buku teks (pelajaran) sementara buku-buku bacaan relatif masih kurang. Permasalahan ini yang sering muncul dalam pelatihan. Demikian juga halnya dengan aktivitas membaca siswa yang sangat memprihatinkan. Kondisi seperti itulah yang banyak didiskusikan dalam kegiatan pelatihan.

Bentuk nyata kerangka pemecahan masalah pelatihan ini adalah sebagai berikut:

1. Perlu adanya kesadaran setiap guru dalam aktivitas membaca baik untuk kepentingan pembelajaran maupun untuk kepentingan karier dan profesi;

2. Aktivitas membaca dimulai dari hal-hal yang kecil, misalnya, membaca kegiatan harian, kegiatan guru dalam mengajar di kelas, dan membaca catatan harian;

3. Perlu diupayakan sarana bacaan yang memadai, seperti buku, bacaan, surat kabar, majalah, dan media informasi lainnya;

4. Perlu adanya kerja sama dengan pers agar mendapatkan wawasan mengenai jenis-jenis tulisan

\section{Kondisi Masyarakat Dampingan}

Penduduk adalah kumpulan manusia yang menempati wilayah geografi dan ruang tertentu. Sedangkan menurut konsep kependudukan yang dimiliki oleh Badan Pusat Statistik itu sendiri merupakan semua orang yang berdomisili di suatu wilayah selama 6 (enam) bulan atau lebih dan atau mereka yang berdomisili kurang dari 6 (enam) bulan tetapi bertujuan untuk menetap dikatakan sebagai penduduk wilayah tersebut. Berdasarkan definisi tersebut, hasil proyeksi penduduk 2014 yang diselenggarakan oleh Badan Pusat Statistik Kota Bandung menunjukan jumlah penduduk Kecamatan Regol pada tahun 2014 mengalami peningkatan dibandingkan tahun 2013, pada saat sensus penduduk 2010 yaitu sebesar 607 jiwa.

Jika dilihat menurut kelurahan tercatat kelurahan Pasirluyu memiliki jumlah penduduk tertinggi dibanding kelurahan lain yaitu sebanyak 17.220 orang, sedangkan Kelurahan Ciateul memiliki jumlah penduduk terendah yaitu 7.769 orang.

Menurut proyeksi penduduk kota Bandung tahun 2014, jumlah penduduk Kecamatan Regol mencapai 81.635 jiwa. Angka tersebut mencakup 40.707 jiwa lakilaki dan 40.928 jiwa perempuan.

Sebagian besar penduduk di Regol memeluk Agama Islam yaitu sebanyak 68.310 jiwa, sedangkan yang memeluk agama Kristen Protestan sebanyak 9.079 jiwa, Kristen katolik 4.031 jiwa, Hindu 912 jiwa, Budha 1.524 jiwa dan agama lainnya 411 jiwa.

Tahun 2015 dengan data tahun 2014, masyarakat Kecamatan Regol memiliki beberapa mata pencarian. Mata pencarian yang tertinggi dengan jumlah 12.196 orang adalah pedagangta dan yang terendah adalah petani dengan jumlah 41 orang. Semakin rendahnya jumlah petani di Kecamatan Regol seiring dengan semakin berkurangnya lahan pertanian di Kecamatan Regol. Letak Kecamatan Regol yang berada di tengah kota membuat lahan pertanian yang dari tahun ke tahun semakin berkurang. Lahan-lahan tersebut dimanfaatkan sebagai tempat usaha atau bahkan tempat tinggal, Kondisi ini memungkinkan sedikitnya jumlah petani Kecamatan Regol yaitu hanya 41 orang saja. Banyaknya tempat pariwisata yang ada di Kecamatan Regol membuat inisiatif dan inovatif dalam mencoba suatu usaha baik perdagangan maupun usaha hiburan lainnya, sehingga jumlah terbesar dipegang oleh kelompok pegawai swasta. Kecamatan Regol memiliki berbagai mata pencarian, diantaranya yaitu PNS,ABRI/ POLRI, pegawai swasta, petani,pedagang, pensiunan, pelajar, mahasiswa dan lainnya. Mata pencarian pedagang 
dengan pegawai swasta memiliki nilai yang berbeda tipis, yaitu hanya berbeda 956 poin. Mata pencarian pedagang sebanyak 12.196 orang sedangkan pegawai swasta sebanyak 13.152 orang.

\section{Partisipasi dan Pelibatan Para Pihak}

Pihak-pihak yang terlibat dalam pelatihan ini terutama adalah para guru itu sendiri, kemudian pihak Dinas Pendidikan Kota Bandung, pihak Yayasan Sebelas Maret, dan pihak dosen-dosen UIN SGD Bandung yang melakukan Pengabdian kepada Masyarakat (PKM) dari Lembaga Penelitian dan Pengabdian kepada Masyarakat (LP2M).

\section{Pelaksanaan Program}

Guru-guru sekolah menengah pertama seyogianya menjadi model, contoh, teladan bagi para siswa. Contoh, teladan seperti itu dapat direalisasikan juga dalam kegiatan membaca. Manakala para guru sudah menjadi contoh yang baik di hadapan para siswa, diharapkan peserta didik dapat meniru perilaku membaca gurunya.

Disadari bahwa aktivitas membaca guru-guru sekolah menengah pertama masih kurang. Melalui pelatihan membaca ini dapat merangsang dan mencerahkan kembali pemikiran, kreativitas, dan pengalaman guru di sekolah, yang selama ini banyak menggeluti dunia pengajaran ditambah dan dikembangkan dengan aktivitas membaca.

Pelatihan membaca dapat menggugah para guru. Kegiatan mereka yang sebagian besar untuk mengajar di depan kelas, ternyata setelah mengikuti pelatihan ini dapat tergugah dan terangsang lagi untuk memberikan pengetahuan mereka pada anakanak didik.

Pelaksanaan pelatihan dilakukan selama 1 (satu) hari. Namun demikian, ada tiga kali pendampingan dilakukan kepada sekolah-sekolah yang gurunya ikut dalam pelatihan ini. Dengan demikian, pelaksanaan program pengabdian ini terjadi dalam empat kali acara, yaitu pelatihan, pendampingan I, pendampingan II, pendampingan III, dan pendampingan IV.

Upaya nyata meningkatkan kemampuan membaca adalah membaca itu sendiri. Oleh karena itu, para guru peserta pelatihan dilibatkan secara aktif dalam aktivitas membaca. Aktivitas membaca dilakukan melalui pemberian contoh bacaan berupa laporan. Semua tahap itu didiskusikan dan dicobakan dalam proses pelatihan di kelas. Para guru merasa senang dan bersemangat mengikuti pelatihan seperti itu, bahkan setelah pelatihan ini mereka menginginkan pelatihan sejenis yang terkait, yaitu latihan menulis.

Oleh karena itu, pelatihan diarahkan bukan hanya pada peningkatan kemampuan membaca, yang dalam hal ini bersifat reseptif. Tetapi pelatihan juga diarahkan pada imajinasi tentang penulis dan hal yang dituliskannya. Demikian juga, pelatihan diarahkan pada bagaimana cara menulis, sehingga terbayang apa yang diperlukan dalam membaca. Falsafah pragmatism di sini sangat diperhatikan. Demikian karena kalau tanpa ada keperluan (pragmatis), kita akan sulit menemukan relevansi dan minat dalam membaca.

Pada realisasinya, sesi ke-3 dan ke-4 dibuat menjadi semacam praktek pelatihan. Dengan demikian, teori dan wawasan hanyalah dua sesi saja. Setelah itu peserta melakukan praktek membaca dan melakukan analisis serta evaluasi sendiri.

Setelah pelatihan pengabdi kemudian melakukan asistensi selama tiga kali ke tempat para guru tersebut mengajar. Ini untuk melakukan wawancara dan observasi dari hasil pelatihan dalam praktek diajarkan kepada anak didik masing-masing peserta.

Guru-guru sekolah menengah pertama seyogianya menjadi model, contoh, teladan bagi para siswa. Contoh, teladan seperti itu dapat direalisasikan juga dalam kegiatan membaca. Manakala para guru sudah menjadi contoh yang baik di hadapan para siswa, diharapkan peserta didik dapat meniru perilaku membaca gurunya.

Disadari bahwa aktivitas membaca guru-guru sekolah menengah pertama masih kurang. Melalui pelatihan membaca ini dapat merangsang dan mencerahkan kembali pemikiran, kreativitas, dan pengalaman guru di sekolah, yang selama ini banyak menggeluti dunia pengajaran ditambah dan dikembangkan dengan aktivitas membaca.

Pelatihan membaca dapat menggugah para guru. Kegiatan mereka yang sebagian besar untuk mengajar di depan kelas, ternyata setelah mengikuti pelatihan ini dapat tergugah dan terangsang lagi untuk memberikan pengetahuan mereka pada anakanak didik.

Pelaksanaan pelatihan dilakukan selama 1 (satu) hari. Namun demikian, ada tiga kali pendampingan dilakukan kepada sekolah-sekolah yang gurunya ikut 
dalam pelatihan ini. Dengan demikian, pelaksanaan program pengabdian ini terjadi dalam empat kali acara, yaitu pelatihan, pendampingan $\mathrm{I}$, pendampingan II, pendampingan III, dan pendampingan IV.

Upaya nyata meningkatkan kemampuan membaca adalah membaca itu sendiri. Oleh karena itu, para guru peserta pelatihan dilibatkan secara aktif dalam aktivitas membaca. Aktivitas membaca dilakukan melalui pemberian contoh bacaan berupa laporan. Semua tahap itu didiskusikan dan dicobakan dalam proses pelatihan di kelas. Para guru merasa senang dan bersemangat mengikuti pelatihan seperti itu, bahkan setelah pelatihan ini mereka menginginkan pelatihan sejenis yang terkait, yaitu latihan menulis.

Oleh karena itu, pelatihan diarahkan bukan hanya pada peningkatan kemampuan membaca, yang dalam hal ini bersifat reseptif. Tetapi pelatihan juga diarahkan pada imajinasi tentang penulis dan hal yang dituliskannya. Demikian juga, pelatihan diarahkan pada bagaimana cara menulis, sehingga terbayang apa yang diperlukan dalam membaca. Falsafah pragmatism di sini sangat diperhatikan. Demikian karena kalau tanpa ada keperluan (pragmatis), kita akan sulit menemukan relevansi dan minat dalam membaca.

Pada realisasinya, sesi ke-3 dan ke-4 dibuat menjadi semacam praktek pelatihan. Dengan demikian, teori dan wawasan hanyalah dua sesi saja. Setelah itu peserta melakukan praktek membaca dan melakukan analisis serta evaluasi sendiri.

Setelah pelatihan pengabdi kemudian melakukan asistensi selama tiga kali ke tempat para guru tersebut mengajar. Ini untuk melakukan wawancara dan observasi dari hasil pelatihan dalam praktek diajarkan kepada anak didik masing-masing peserta.

\section{Analisis Hasil Evaluasi}

Setelah pelatihan ini berlangsung, hasilnya sangat memuaskan para peserta. Para guru sekolah menengah pertama dan kepala sekolah sangat bersungguh-sungguh mengikuti pelatihan ini, hal ini terbukti dari hasil diskusi di kelas, ada peserta yang mendemonstrasikan hasil pengamatan dalam pelajaran Matematika, pengalaman membaca dan melaporkan hasil observasi/percobaan dalam pelajaran IPA, dan lain-lain. Semua itu menunjukkan bahwa para guru dan kepala sekolah memiliki bahan dan pengalaman yang memadai tentang ha 1 itu.

Dari hasil pemantauan dan evaluasi panitia, respon para peserta sangat antusias dengan materimateri yang disampaikan. Bentuk respon mereka terdiri dari berbagai pertanyaan interaktif antara peserta dan narasumber. Bahkan penugasanpenugasan yang diberikan oleh para narasumber dilaksanakan dengan baik oleh peserta.

Faktor pendorong atau pendukung yang sangat besar dari semua pihak dalam kegiatan pelatihan ini adalah semua pihak yang berkepentingan dengan peningkatan mutu sumber daya manusia, dalam hal ini sumber daya guru. Pihak-pihak yang berkepentingan adalah Pusat Pengabdian kepada Masyarakat beserta pihak Dinas Pendidikan Kecamatan Regol Kota Bandung yang bersedia berpartisipasi dalam kegiatan ini. Semua komponen itu saling mendukung dan kerja sama yang baik sehingga program pelatihan yang didanai oleh dana rutin Universitas Islam Negeri Sunan Gunung Djati Bandung tahun anggaran 2017 ini berjalan sesuai dengan rencana.

Faktor penghambat yang paling menonjol adalah ketersediaan waktu dari peserta pelatihan. Karena mereka sebagai guru dan kepala sekolah yang terikat dengan peraturan kepegawaian, maka faktor waktulah yang menjadi penghambat. Akan tetapi, berkat kebijakan dialog dengan para guru setempat, akhirnya dapat diputuskan waktu pelaksanaannya.

Di samping waktu, kesibukan dosen juga menjadi salah satu kendala. Namun, hal ini dapat diatasi sebab waktu yang dipergunakan adalah ketika para dosen tidak melakukan kegiatan akademik di kampus.

Faktor penghambat yang paling urgen dan segera dicarikan pemecahannya adalah ihwal dana yang dipandang masih relatif kecil. Oleh karena itu, anggaran pengabdian untuk masa yang akan datang agar ditingkatkan lagi sehingga mutu pengabdian dapat ditingkatkan

Singkatan yang sudah umum seperti seperti IEEE, SI, MKS, CGS, sc, dc, and rms tidak perlu diberi keterangan kepanjangannya. Akan tetapi, akronim yang tidak terlalu dikenal atau akronim bikinan penulis perlu diberi keterangan 
kepanjangannya. Sebagai contoh: Model pembelajaran MiKiR (Multimedia interaktif, Kolaboratif, dan Reflektif) dapat digunakan untuk melatihkan penguasaan keterampilan pemecahan masalah. Jangan gunakan singkatan atau akronim pada judul artikel, kecuali tidak bisa dihindari.

\section{PENUTUP}

Kegiatan pelatihan membaca bagi guru-guru sekolah menengah pertama dan kepala sekolah mendapat respons yang positif. Hal ini terbukti dari hasil pengolahan angket yang disebarkan kepada para peserta. Peserta memandang positif dan sangat bermanfaat, bahkan kegiatan seperti ini dapat terus diupayakan di masa yang akan datang. Para peserta tidak hanya terbatas kepada kepala sekolah dan guru senior saja tetapi guru-guru lain juga dapat berpartisipasi dalam kegiatan sejenis.

Kegiatan pelatihan sejenis dapat dikembangkan terutama untuk penulisan karya ilmiah. Para guru terutama golongan III/d merasa kesulitan untuk menulis karya ilmiah. Oleh karena itu, pelatihan berikutnya yang dipandang mendesak oleh guru di lapangan adalah pelatihan penulisan karya ilmiah untuk kepentingan kenaikan jabatan dan pangkat. Hal inilah yang perlu mendapat respons perguruan tinggi, dalam hal ini UIN SGD Bandung untuk terus berkiprah dalam pembinaan dan pengembangan jenjang pendidikan dasar..

\section{DAFTAR PUSTAKA}

Applebee, A.N.; J.A. Langer; M. Nystrand; dan A. Gamoran. (1993). Instructional Scaffolding: Reading and Writing as Natural Language Activities. Urbana, Illinois: National Council of Teachers of English.

Atkins, P.W. (1999). Kimia Fisika. Terjemahan Kartahadiprojo Irma I, edisi ke-2. Jakarta: Erlangga.

Baroody, A.J. (1993). "Fostering the mathematical learning of young children. In B. Spodek (Ed.), Handbook of Research on the Education of Young Children. New York: Macmillan.

Cai, J.; Mary S. Jakabcsin; dan Suzanne Lane LDRC. (1996). Assesing Student's Mathematical Communication. In School Science and Mathematics. Wiley Online Library. $\quad$ URL: http://onlinelibrary.wiley.com/doi/10.1111/j.19 49-8594.1996.tb10235.x/abstract [10/2/2017].

Collins, William; Linda Dritsas; Patricia FreyMason; Arthur C. Howard; Kay McClain; David D. Molina; Beatrice Moore-Harris; Jack Ott; Ronald S. Pelfrey; Jack Price; Barbara Smith; and Patricia S. Wilson. (1998). Mathematics: Applications and Connections. New York: Glencoe/McGraw Hill.

Conant, James Bryant. (1995). American High School Today. [1959]. New York: McGraw Hill Inc.

Ismail, Taufik. (2003). Agar Anak Bangsa Tak Rabun Membaca Tak Pincang Mengarang. Pidato Pengukuhan. Yogyakarta: UNY.

NTCM. (2000). Principles and Standards for School Mathematics. Reston, VA: National Council of Teachers of Mathematics.

Rifai, Mien A. (1997). Pegangan Gaya Penulisan, Penyuntingan dan Penerbitan Karya Ilmiah Indonesia. Cetakan kedua. Yogyakarta: Gadjah Mada University Press.

Tarigan, H.G.; Aceng Ruhendi Saifullah; dan Kholid A. Harnas (eds.). (1989). Membaca Dalam Kehidupan. Bandung: Angkasa.

Taufik, Mohammad; N.S. Sukmadinata, Ishak Adulhak, dan Bernard Y. Tumbelaka. (2010). Potret Pembelajaran IPA (Fisika) Sekolah Menengah Pertama Di Kota Bandung. Seminar Nasional HFI 2010 Pendidikan dan Penelitian Fisika dalam Mengantisipasi Perubahan Fenomena Alam. Bandung: Universitas Padjadjaran.

UNDP. (2016). Human Development Report 2016: Human Development for Everyone. New York: United Nations for Development Programme.. 